\title{
URUBUS-DE-CABEÇA-PRETA (CORAGYPS ATRATUS), GARÇAS-BRANCAS- GRANDES (ARDEA ALBA) E PEIXEIROS NA PEDRA DO PEIXE: EXPERIÊNCIAS CONVIVIAIS INTERESPECÍFICAS NA CIDADE
}

\author{
Flávio Leonel Abreu da Silveira ${ }^{1}$ \\ Matheus Henrique Pereira da Silva ${ }^{2}$
}

O ensaio que apresentamos é fruto de nossa pesquisa etnográfica realizada na Pedra do Peixe - situada junto ao Mercado de Ferro, ou do Peixe - no Complexo do Ver-o-Peso, Belém (PA). Nele apresentamos imagens obtidas pelos dois autores ${ }^{3}$ durante os trabalhos de campo e buscamos associá-las a fim de configurarem narrativas imagéticas em diálogo com o texto. A intenção, ainda, é a de aproximar imagens de diferentes épocas às contemporâneas, de maneira a extrairmos elementos interpretativos sobre a vida urbana ao longo do tempo e, assim, de evocarmos as reverberações imagéticas da existência da avifauna nesta cidade, especialmente quanto a presença dos urubus-de-cabeça-preta (Coragyps atratus). Eles figuram no locus da pesquisa (e seus arredores) há bastante tempo. Os panoramas do pintor italiano Joseph León Righini são registros das práticas paisageiras à época, mas também da presença daqueles rapineiros. No caso da vista do Largo das Mercês ${ }^{4}$, de 1867, por exemplo, temos um cenário da Belém do século XIX não muito distante do já secular Ver-o-Peso onde as aves aparecem em sobrevoo.

\footnotetext{
${ }^{1}$ Universidade Federal do Pará, Brasil.

${ }^{2}$ Universidade Federal do Pará, Brasil.

${ }^{3}$ As imagens foram obtidas durante a pesquisa de campo na Pedra do Peixe, inclui-se, ainda, neste ensaio algumas imagens obtidas por Raphael das Mercês, bolsista PIBIC que também realiza pesquisas na área.

${ }^{4}$ O Panorama do Pará em Doze Vistas, de Joseph León Righini, é constituído por litografias que apresentam paisagens citadinas onde a presença constante dos urubus demonstra que eles figuram as paisagens belenenses desde longa data. A vista do "Largo do Quartel" (atual Praça da Bandeira), situada não muito longe do local da pesquisa é outro exemplo de seu comparecimento nos lugares. A presença da espécie também é registrada em outros panoramas. Para tanto ver o site do Centro de Memória da UFPA http://www.ufpa.br/cma/imagenscma.html
} 


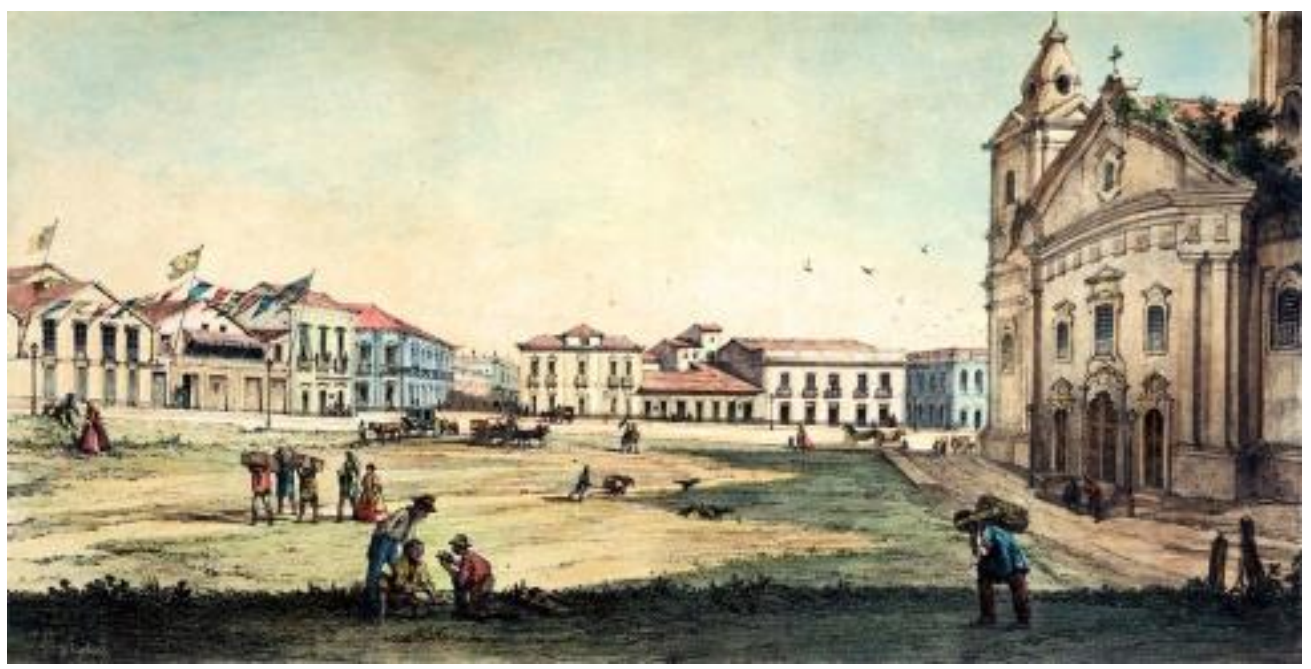

Sabe-se que a cidade de Belém, devido a sua importância no contexto amazônico mais intensamente a partir do XVIII - apresenta um rico acervo de imagens que dão a conhecer suas diversas feições ao longo do tempo. Aderir às imagens produzidas sobre a cidade é uma forma sensível de olhá-la - há aqui certa arqueologia das memórias, uma visada etnográfica a sua duração (Rocha e Eckert, 2013) - e permite vislumbrarmos aspectos diversos do processo civilizacional que se assentou na zona do Equador, cujas dinâmicas urbanas estão atravessadas por congraçamentos e tensões de distintas ordens. Tais dinamismos implicam expressões culturais em jogo e formas plurais de natureza, as quais contribuem no vir a ser das paisagens urbanas a partir de suas manifestações compartilhadas na urbe amazônica. Trata-se de formas paisageiras muito próprias no contexto brasileiro, como são aquelas do Complexo do Ver-o-Peso, considerado um Patrimônio Nacional ${ }^{5}$ no Norte do país.

O complexo do Ver-o-Peso está localizado junto ao Centro Histórico da cidade de Belém (PA). Ele, atualmente, compreende uma área de $26.500 \mathrm{~m}^{2}$ organizada em diversos setores, tais como: Mercado de Peixes, Mercado de Carne, Feira Livre (de frutas e legumes, áreas dedicadas a extratos e diversos chás, às farinhas, grãos e temperos e, ainda, uma área de alimentos preparados), além da Feira do Açaí. O local onde situa-se o mercado é banhado pela baía de Guajará, massa hídrica que resulta do encontro das fozes dos rios Guamá e Acará.

\footnotetext{
${ }^{5}$ Ver http://portal.iphan.gov.br/pagina/detalhes/828
} 


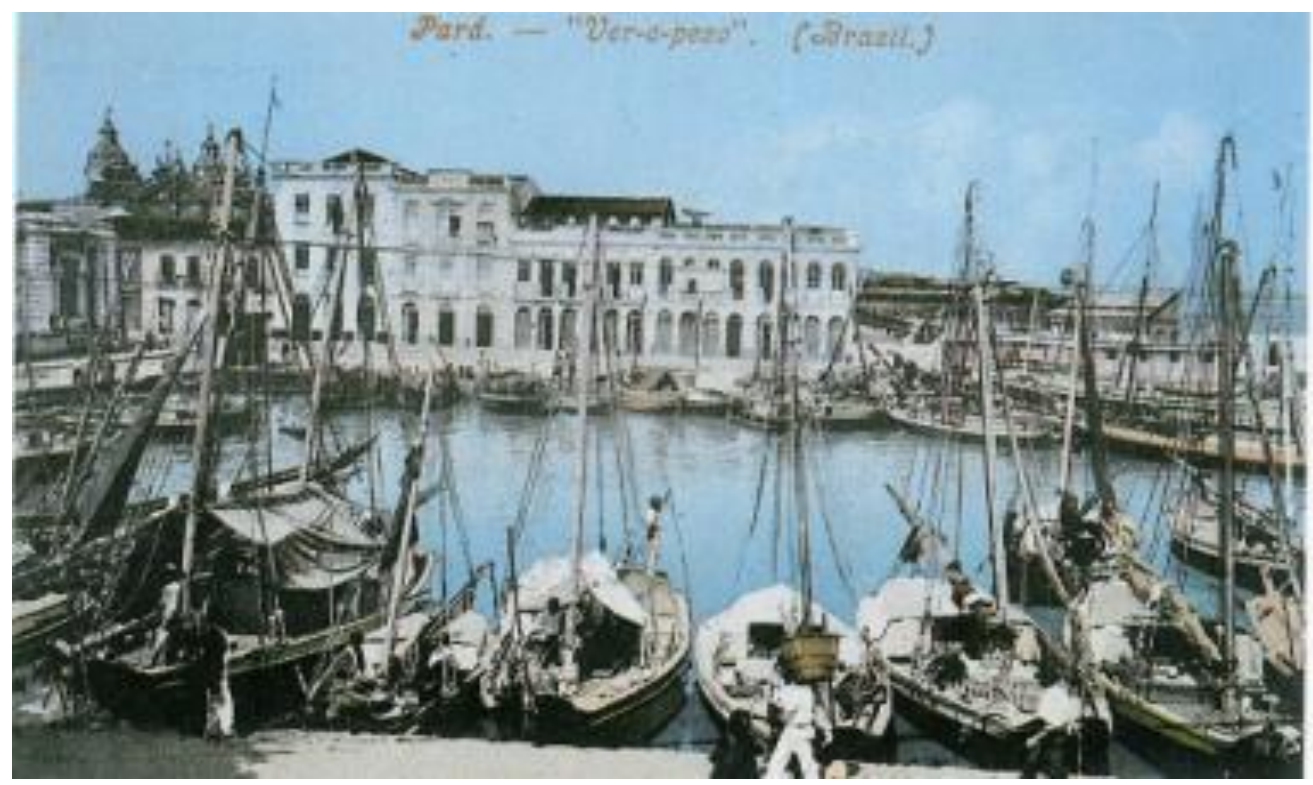

O Mercado do Peixe e sua doca são imagens icônicas nas paisagens de Belém. Suas figurações estão associadas à imagens mais recuadas relacionadas a Belle Époque paraense - são de caráter propagandístico, por isso capazes de seduzir tanto os empreendedores que queiram investir na cidade, quanto o "olhar do turista" (Urry, 1992) voltado ao fotográfico, ou mesmo, são direcionadas a ele sob a forma de cartão postal, de souvenir, enfim, como um suporte de memórias afetivas e pessoais sobre um lugar na cidade amazônica.

Para o caso deste ensaio, as representações iconográficas em que urubus, garças e pescadores aparecem como temas centrais de obras, nota-se, são frequentes nas xilogravuras do artista plástico Oswaldo Goeldi (1895-1961), ou mesmo em determinadas gravações do artista onde interagem. Oswaldo, filho do zoólogo suíço Emílio Goeldi, viverá até os seis anos de idade em Belém. Certamente as paisagens amazônicas marcaram intensamente a visão de mundo do desenhista ${ }^{6}$.

\footnotetext{
${ }^{6}$ Acima: Noite de Neblina (xilogravura, 1940). Abaixo à esquerda: Urubus (1919), a direita: Pescador, nanquim, s/d. http://www.catalogodasartes.com.br/Lista_Obras_Biografia_Artista.asp?idArtista=167
} 

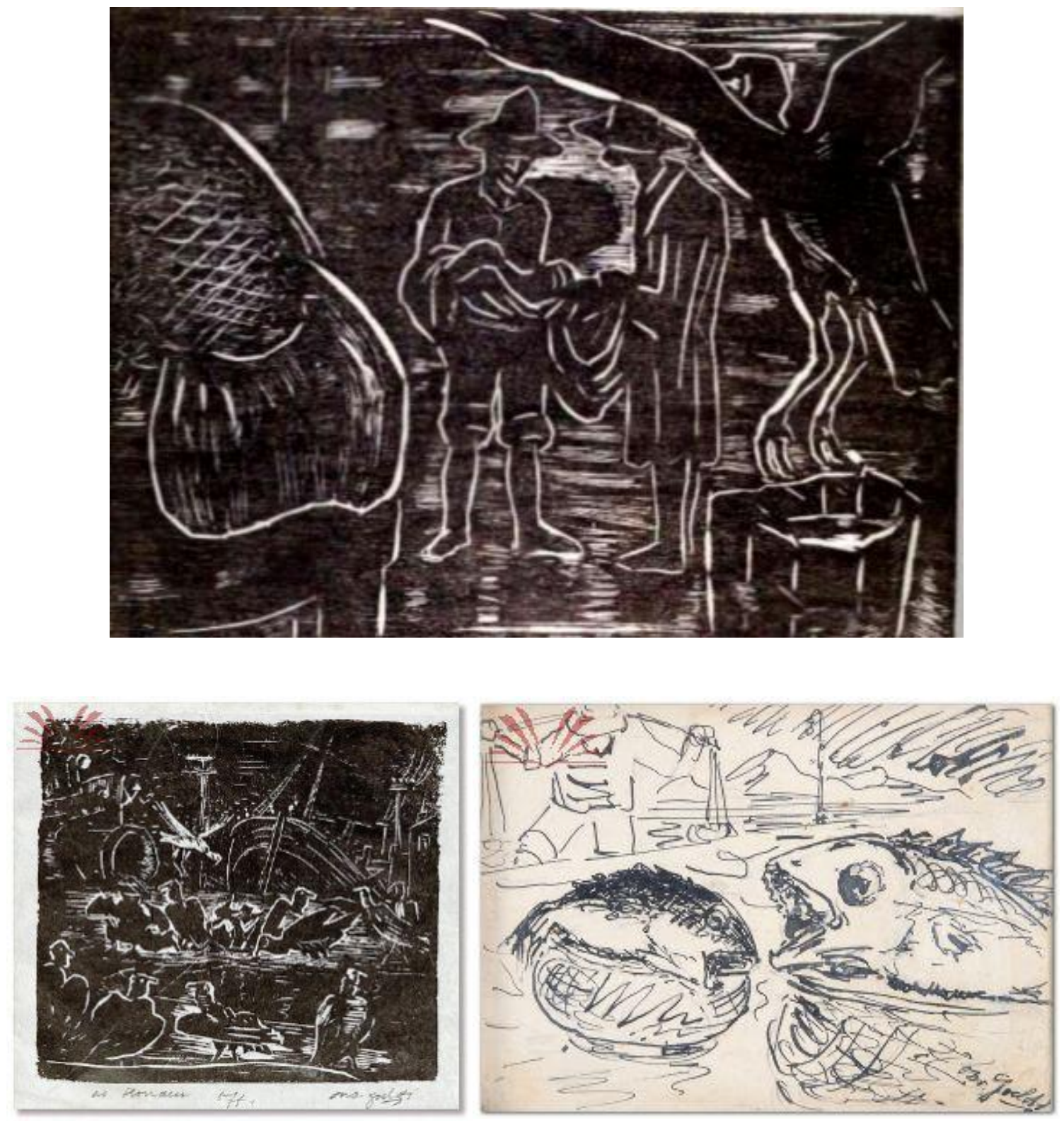

A perspectiva de um guia sentimental e histórico para a cidade de Belém, por exemplo, surge na obra de Leandro Tocantins (1987 [1963]): nela a figuração da doca do Mercado de Ferro tem sua poética manifesta na gravura da série desenhada por Percy Lau que ilustra o livro. A imagem em questão indica as dimensões do sensível na vida social belenense, especialmente ao evocar os entrelaçamentos formais de coisas e suas agências (Miller, 2013) ao praticante da cidade, ao viajante que ambiciona visitar o lugar. 


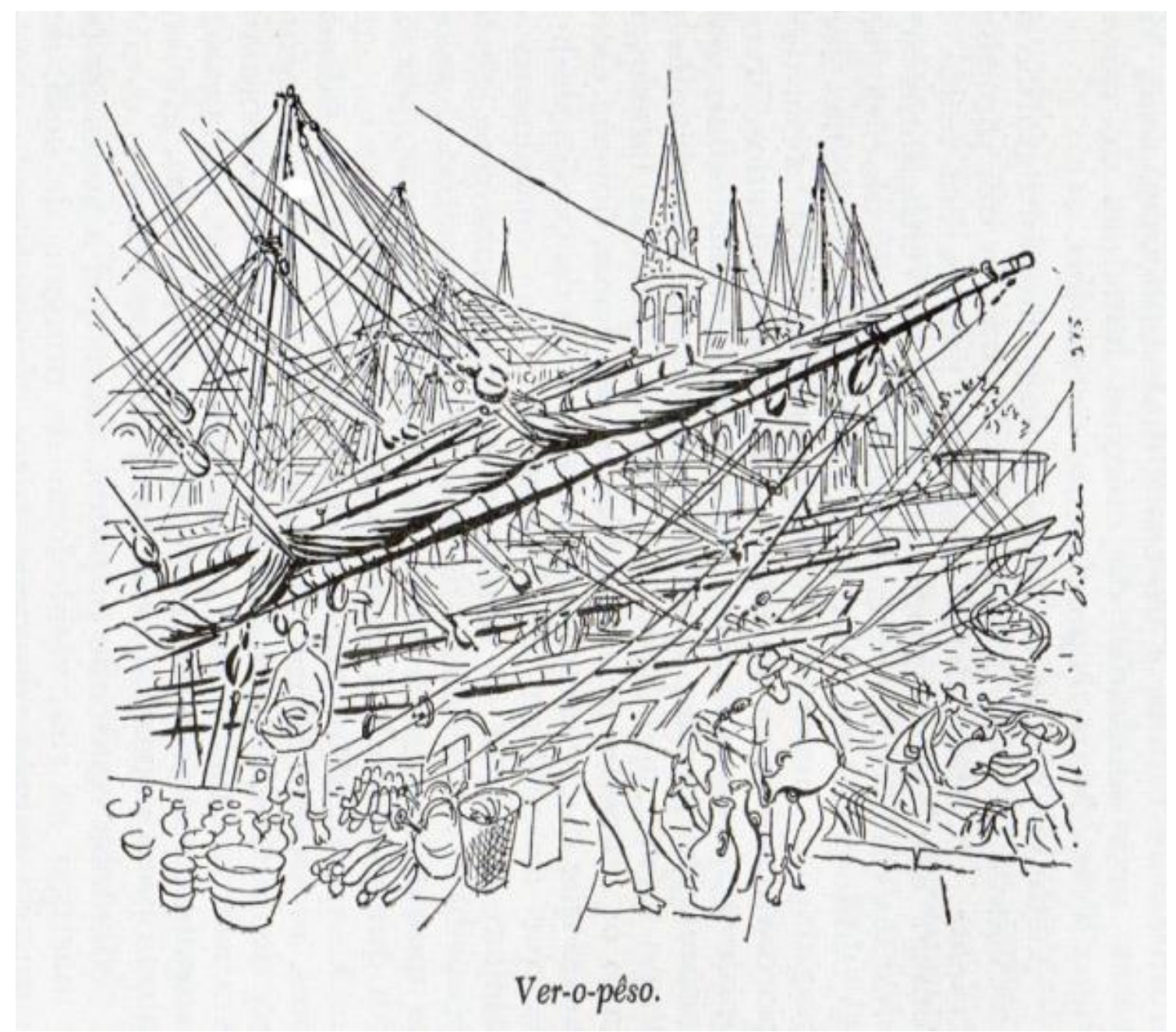

Por outro lado, as representações de caráter pictórico do mercado, reveladas pela perspectiva do artista interessado pelo mundo urbano, apresentam paisagens e panoramas citadinos onde a sua presença se intensifica, como é o caso da obra de Luiz Gonzaga Neves, intitulada Baixa-Mar na Doca do Ver-o-Peso ${ }^{7}$, de 1966.

\footnotetext{
${ }^{7}$ Óleo sobre tela. Acervo do Museu de Arte de Belém (MAB).
} 

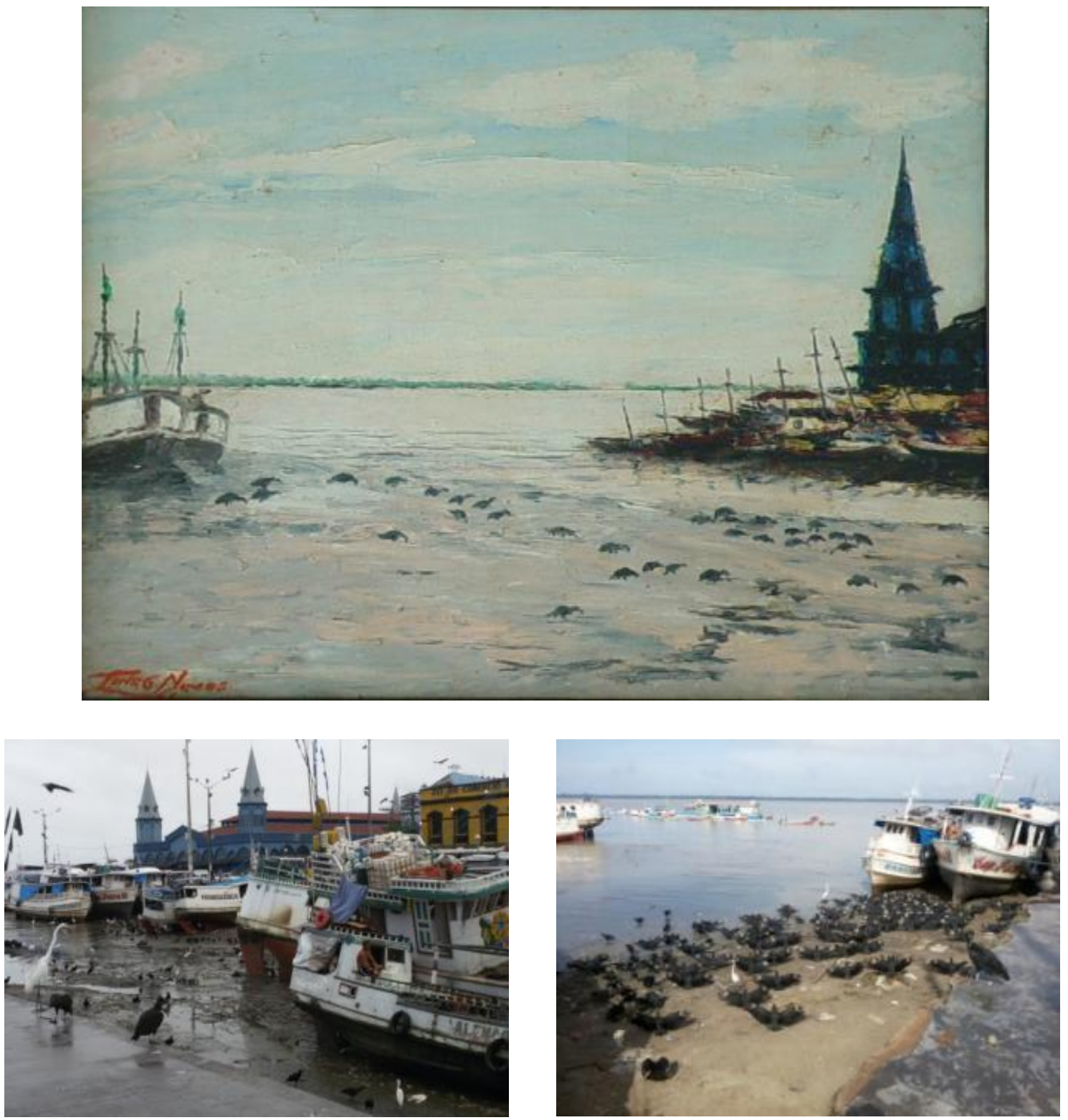

De qualquer forma imagens antigas ou contemporâneas, independente do seu suporte e das intenções pelas quais foram obtidas/produzidas, expressam nuanças das configurações de formas sociais humanimais de interação no mundo urbano belenense por coletivos distintos, como manifestações sensíveis no trajeto antropológico (Durand, 1989) com os não-humanos, ou ainda, como devir ao longo das paisagens praticadas.

A partir deste variado material iconográfico - fotografias atuais e antigas, gravuras, pinturas - um leque de imagens sobre as relações interespecíficas se apresenta, deflagra-se um amplo campo de possibilidades interpretativas (Velho, 1994) acerca do mundo urbano belenense e suas dinâmicas não-lineares com o tempo (Rocha e Eckert, 2005; Silveira, 2016). Neste sentido, imagens contemporâneas envolvendo 
performances artísticas auxiliam-nos a compreender por intermédio da potência das imagens sobre o Ver-o-Peso, certas tensões e assimetrias de forte acento simbólico na conformação sócio-espacial daquele contexto de intensas sociações. Quando todos calam, da artista visual paraense Berna Reale, é uma imagem de fulgurações impactantes. Por outro lado, de maneira mais leveas críticas aos dilemas da vida social belenense vibram nas imagens evocadas no videoclipe da música No meio do pitiư ${ }^{8}$, de Dona Onete, cantora paraense cujo ritmo musical pode ser denominado de carimbó chamegado 9 .

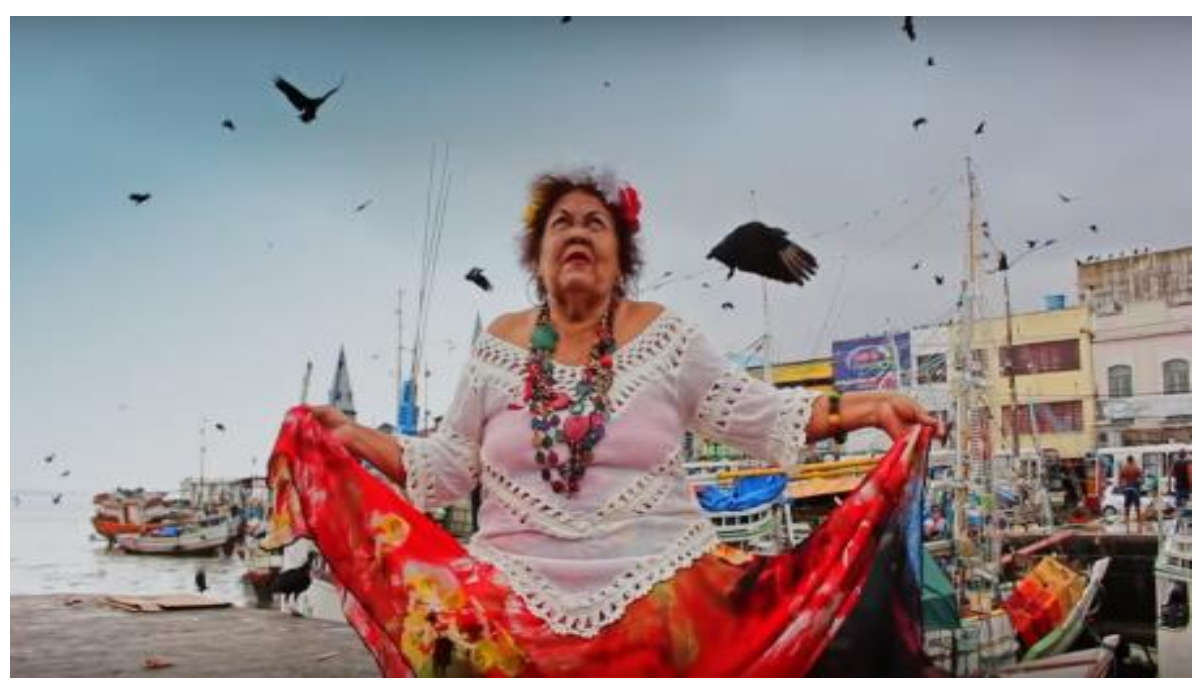

A garça namoradeira

Namora o malandro urubu

Eles passam a tarde inteira

Causando o maior rebu

Na doca do Ver-o-Peso

No meio do Pitiú

No meio do Pitiú,

no meio do Pitiú

Eu fui cantar carimbó

Lá no Ver-o-Peso

Urubu sobrevoando

\footnotetext{
${ }^{8}$ Pitiú é uma expressão que indica mau cheiro, especialmente aquele proveniente de espécies de peixes, no entanto, pode relacionar a outras formas de odores fétidos.

${ }^{9}$ No meio do pitiúé a nona faixa do CD Banzeiro, lançado em 23 de junho de 2016 pelos selos Ná Music/Natura Musical, de Dona Onete. Ver http://www.donaonete.com.br/
} 
Alô, pessoal da Pedra! Alô, os barqueiros

Todas as pessoas que trabalham

Com esse peixe maravilhoso do meu Pará

Ambas as performances parecem indicar dimensões da vida social belenense: por um lado, pelo aspecto festivo da musicalidade e das formas de sociabilidade no mundo urbano contemporâneo de Belém, que evocam imagens da malandragem e sedução; mas também pelo caráter de relativo descaso na quase ausência de políticas públicas para o lugar, especialmente no que se refere ao saneamento urbano, às distâncias entre saberes cotidianos e saberes técnicos no que tange às relações estabelecidas com os detritos de origem não orgânica, por exemplo.

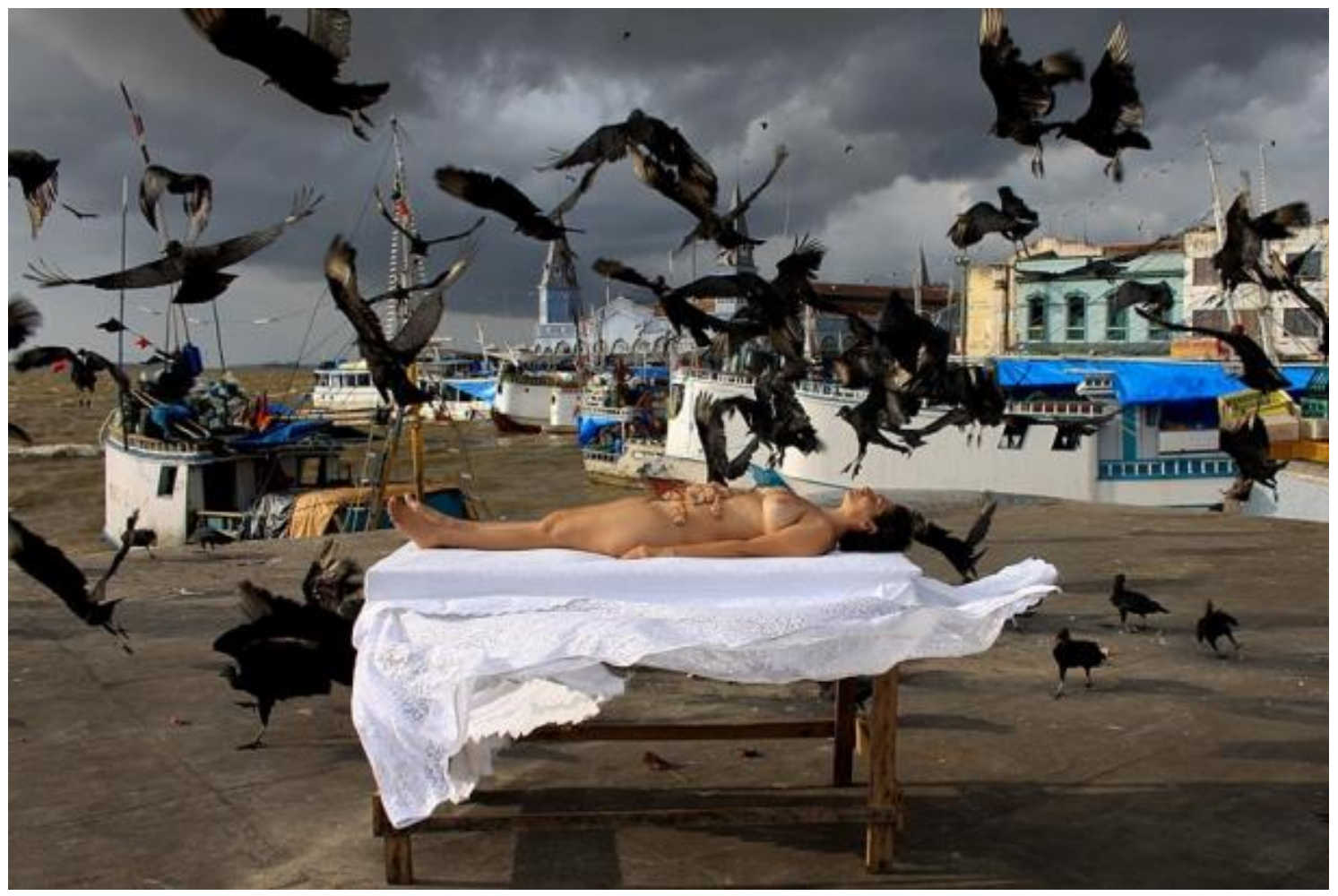

As figurações animais no mundo urbano auxiliam a obtenção de imagens que seriam próprias às cenas da vida urbana, neste caso, a partir de uma etnografia voltada ao acompanhamento das atividades diárias que envolvem humanos (trabalhadores, habitués) e a avifauna na Pedra do Peixe, local onde ocorrem agenciamentos diversos, relacionados aos usos do espaço pelos coletivos humanimais de diferentes maneiras, diretamente relacionados à água, ao descarte do lixo, bem como às práticas de higiene 
(ou a sua ausência) que demonstram as complexidades urbanas desde longa data naquele contexto, principalmente quando se trata de lidar com noções de limpo e sujo (Douglas, 1976) e, a partir daí,de certas imagens odoríferas que impregnam as narinas sob a forma de "pitiú".

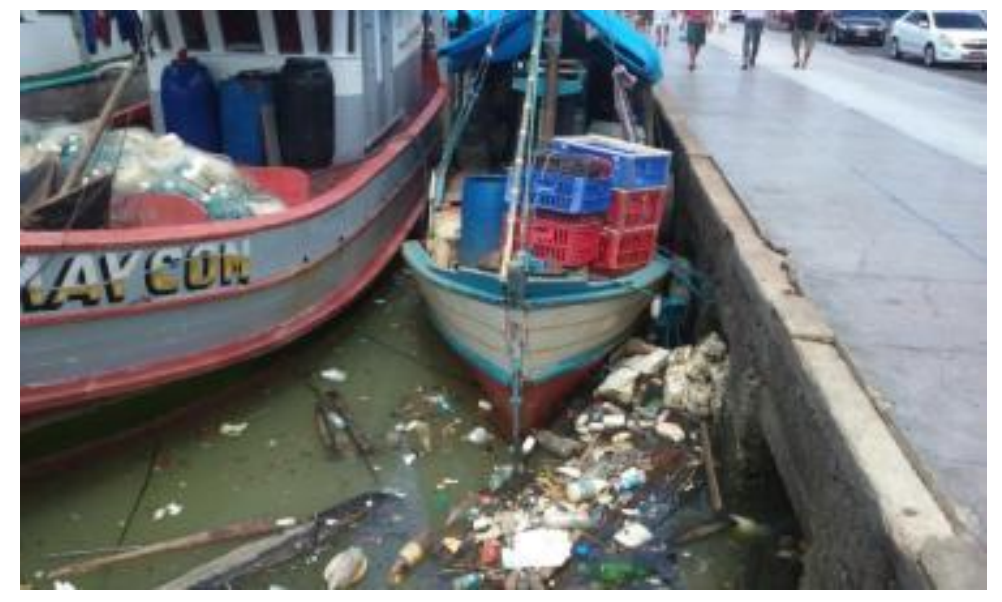

Na chamada Pedra do Peixe as manhãs são marcadas pela intensa circulação de pessoas (trabalhadores diversos, transeuntes, turistas, entre outros) e alguns representantes da avifauna urbana que convivem com os humanos naquele local, onde as pessoas "tratam"/evisceram os peixes e comercializam o pescado a céu aberto. Tratase, mais precisamente, de grandes grupos de urubus-de-cabeça-preta e garças-brancasgrandes, além de não-humanos outros (pombos, gatos, cães, ratos, baratas) que frequentam comumente o lugar em busca de alimentos disponibilizados pelas atividades dos coletivos humanos. Assim, os humanos realizam diversas formas laborais e de sociabilidade efetuadas em distintas formas de frequentação do espaço urbano, formas que apresentam relações com o mundo rural como apontam os estudos de Lima (2008) e Leitão $(2010 ; 2016)$.

Diariamente as aves sobrevoam o local que é intensamente praticado pelas pessoas que circulam pela á, labutam e exercem diversas formas de sociabilidade. Além disso, os animais pousam sobre as estruturas urbanas presentes distribuídas na espacialidade do lugar (casarões, igrejas, postes, muradas, lixeiras, caixas, calçadas, barcos, motocicletas, entre outros) e às margens da baía, quando em dias muito quentes se hidratam e resfriam nas águas rasas, ou mesmo, aproveitam para tomar banhos de sol. 

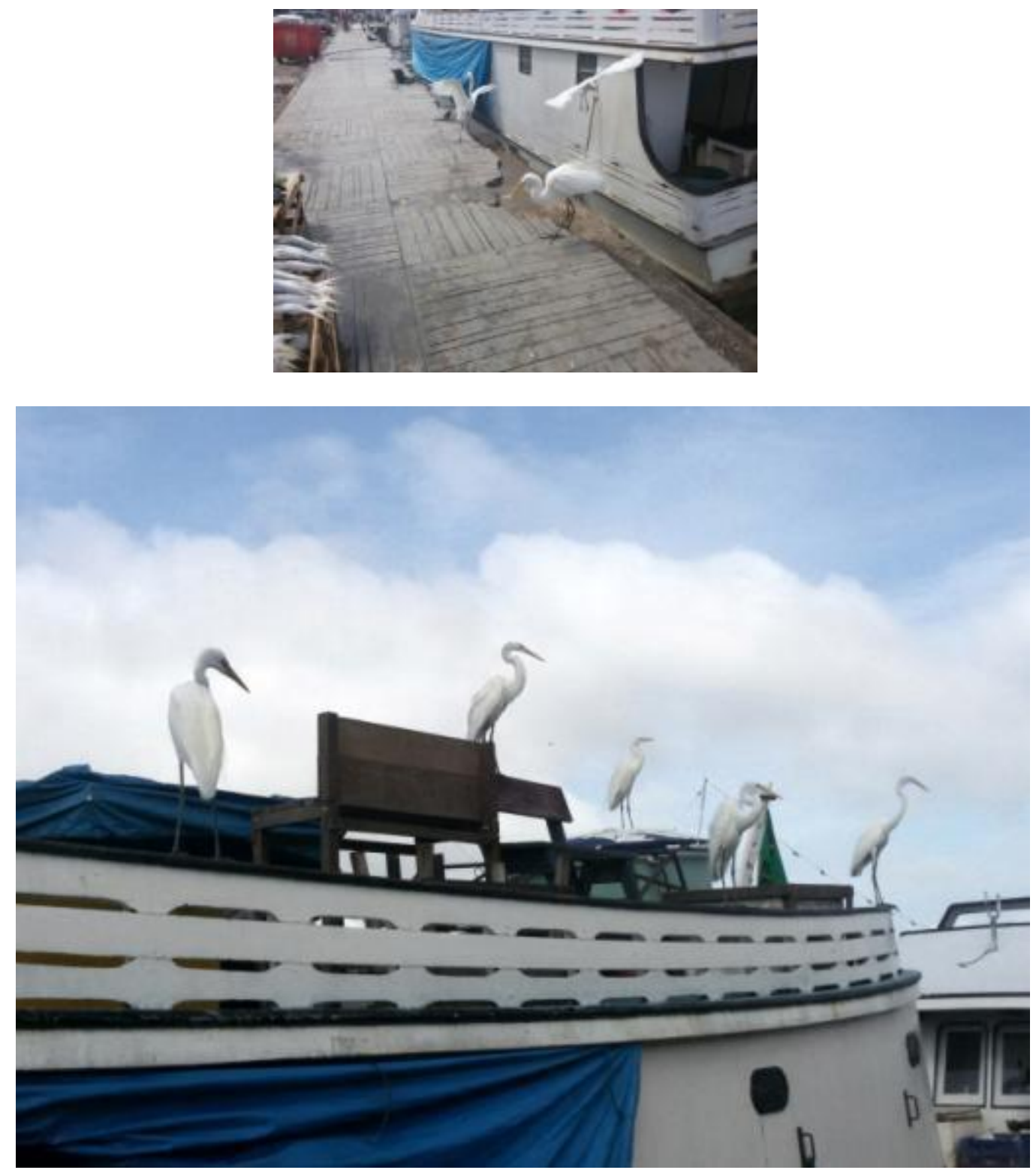


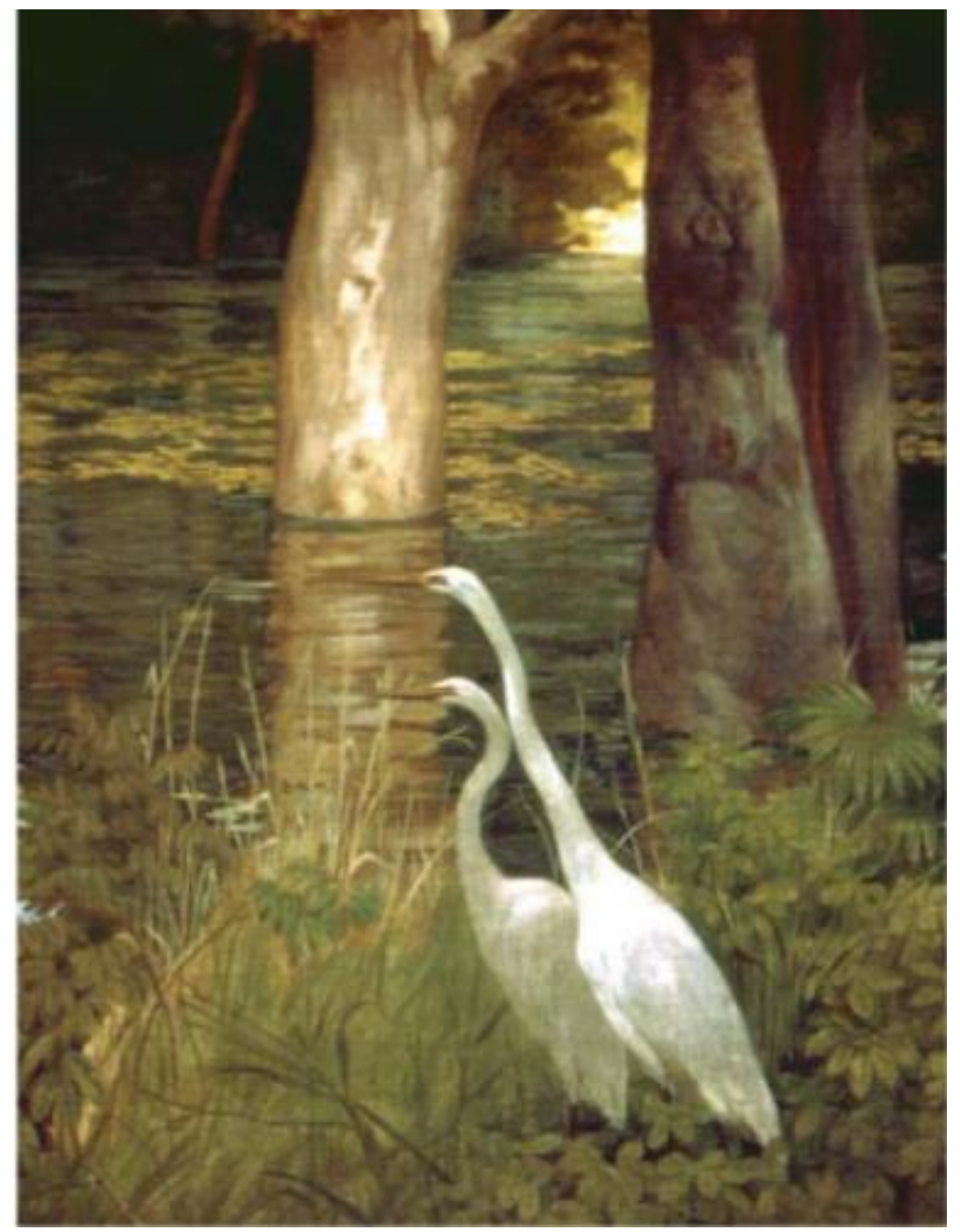

Detalhe dos painéis decorativos do Salão Nobre do Teatro Amazonas, intitulado As Garças, conforme Daou (2007).

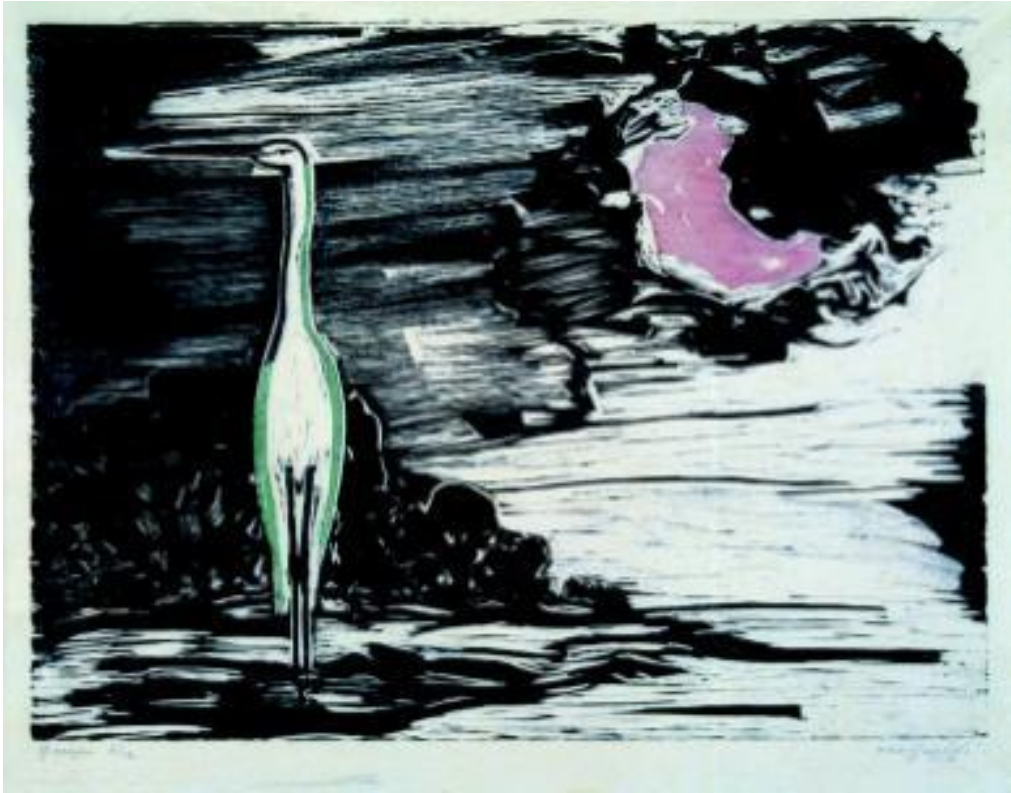

A garça - Oswaldo Goeldi, xilogravura, 1940. 

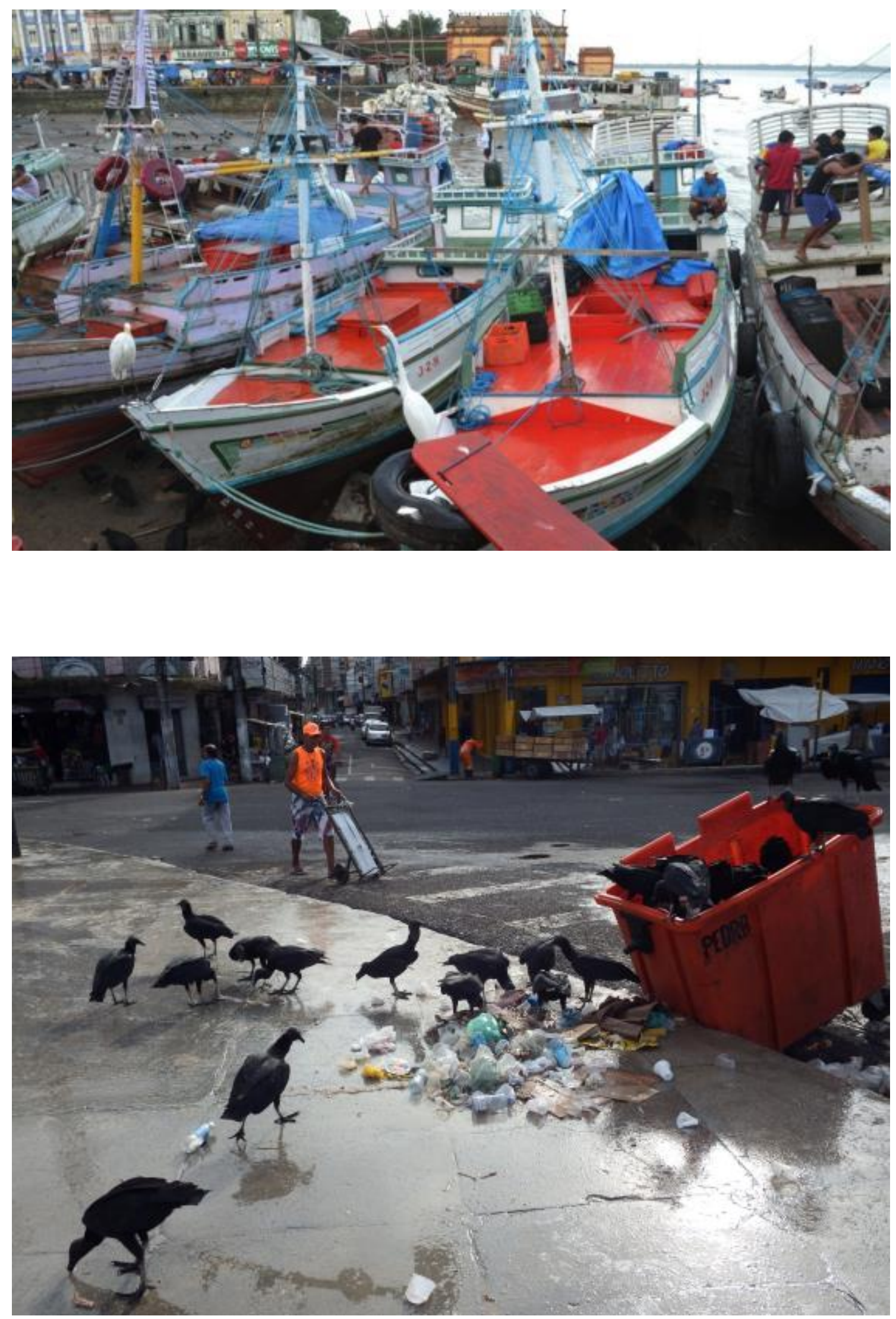
Os (des)encontros entre humanos e não-humanos estão associados às agências voltadas ao compartilhamento de espaços pelos coletivos humanimais e as negociações proxêmicas de interação, visto que diariamente as aves recebem porções/pedaços/resíduos de peixes, sobretudo de parte dos peixeiros.

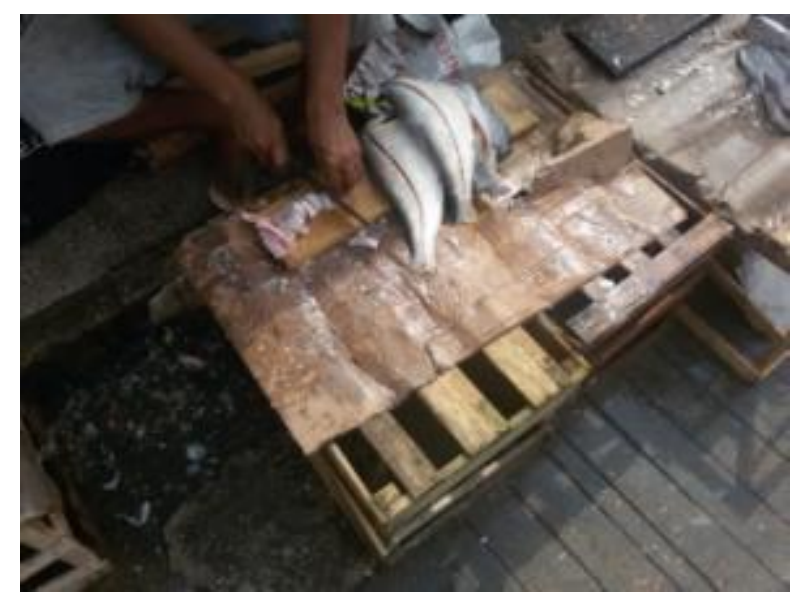

Os profissionais realizam as atividades de evisceração dos animais visando a sua comercialização. Assim, as aves estão diretamente relacionadas à eliminação de detritos orgânicos considerados resíduos ou lixos pelos trabalhadores, pois servem de alimento aos animais cotidianamente, restando como um subproduto de sua labuta na Pedra do Peixe.

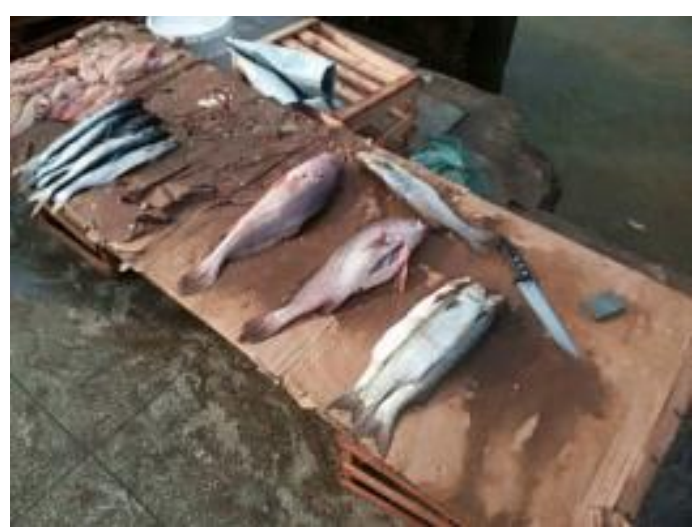



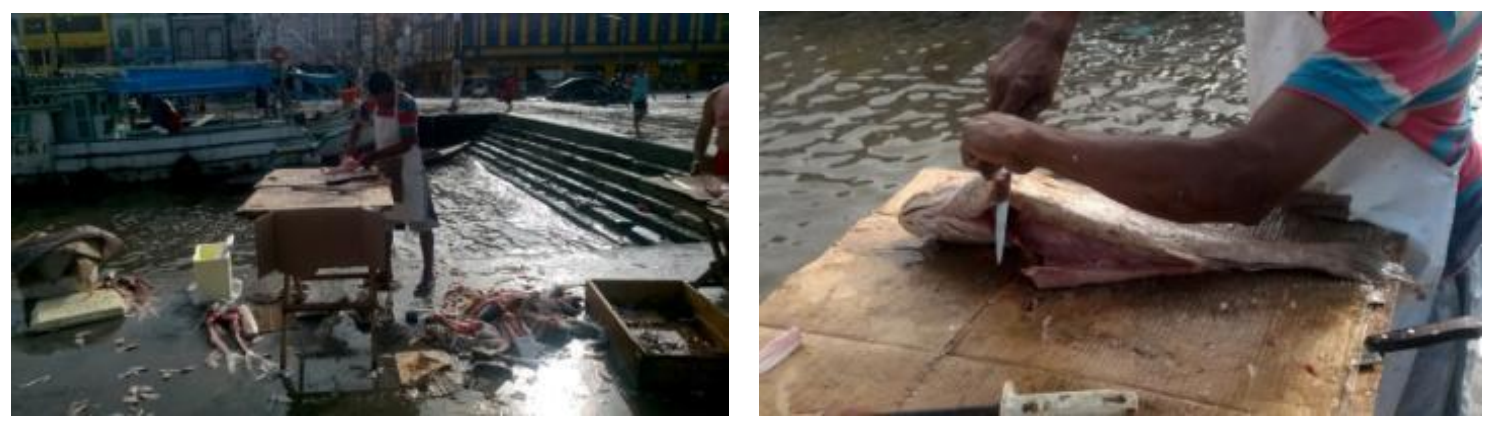

Durante a predação das carcaças é possível que ocorra algum enfrentamento entre os diversos indivíduos ali relacionados (das garças ou dos urubus entre si, configurando, assim, interações de competição intraespecíficas), ou entre as duas espécies (interações interespecíficas), fenômeno movido pela disputa de alimentos ofertados pelos humanos - é possível ouvir de peixeiros que os urubus "não podem" com as garças, evidenciando a disputa agonística entre ambas espécies. Portanto, os humanos figuram como agentes de interações interespecíficas a partir de gestos técnicos de cortar, eviscerar, "tratar", “arrumar" os peixes e, posteriormente, de lançar partes de seus corpos às aves enquanto uma forma de descarte próprio a sua labuta.

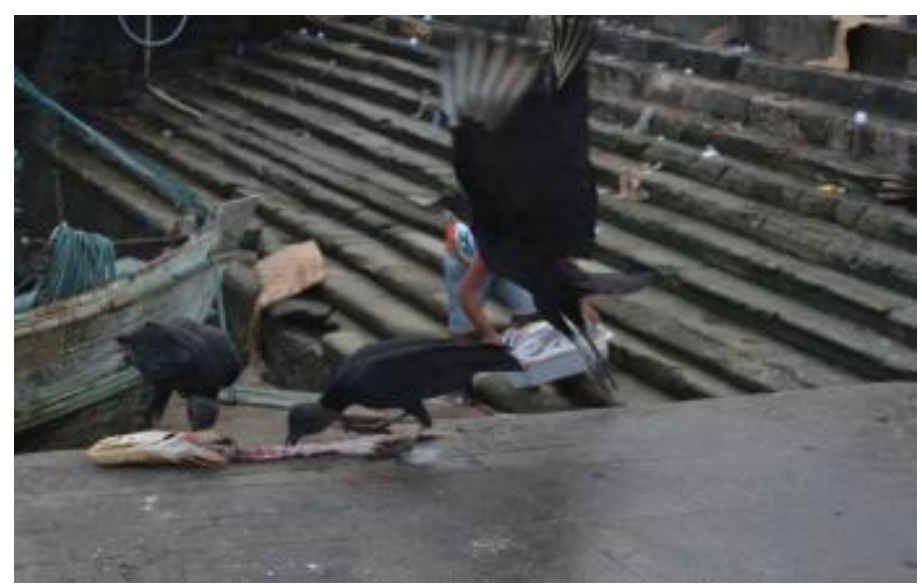



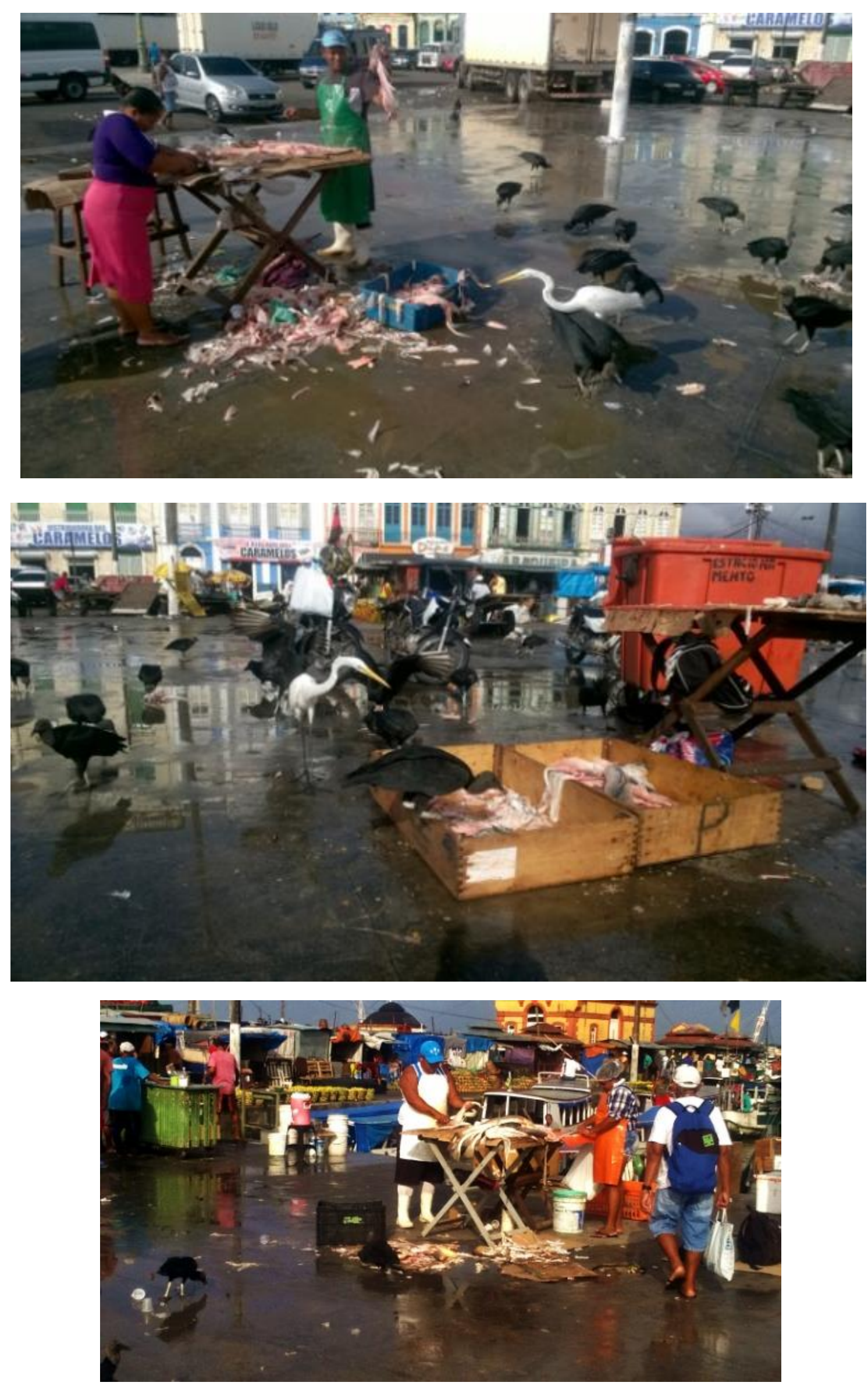

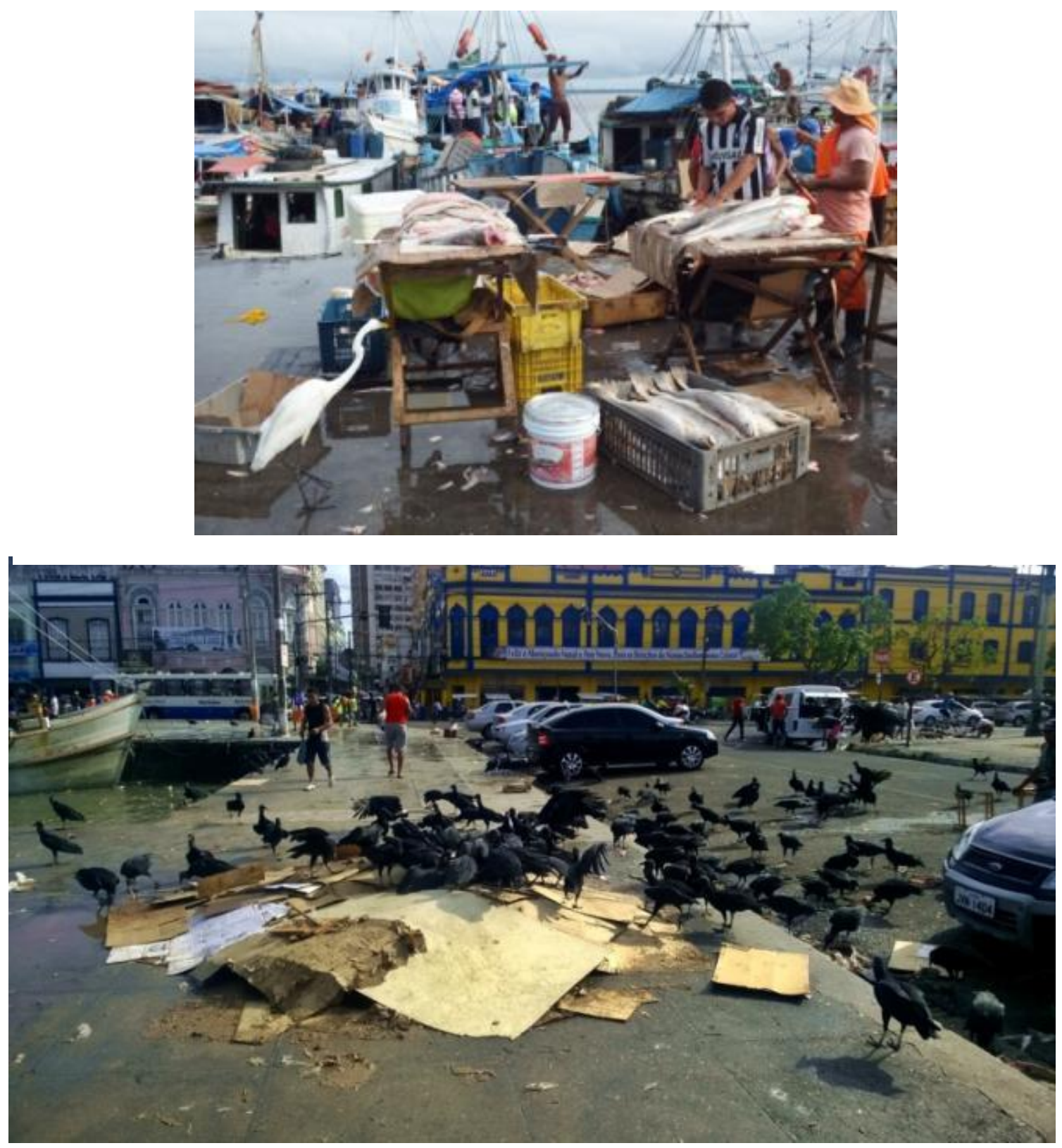


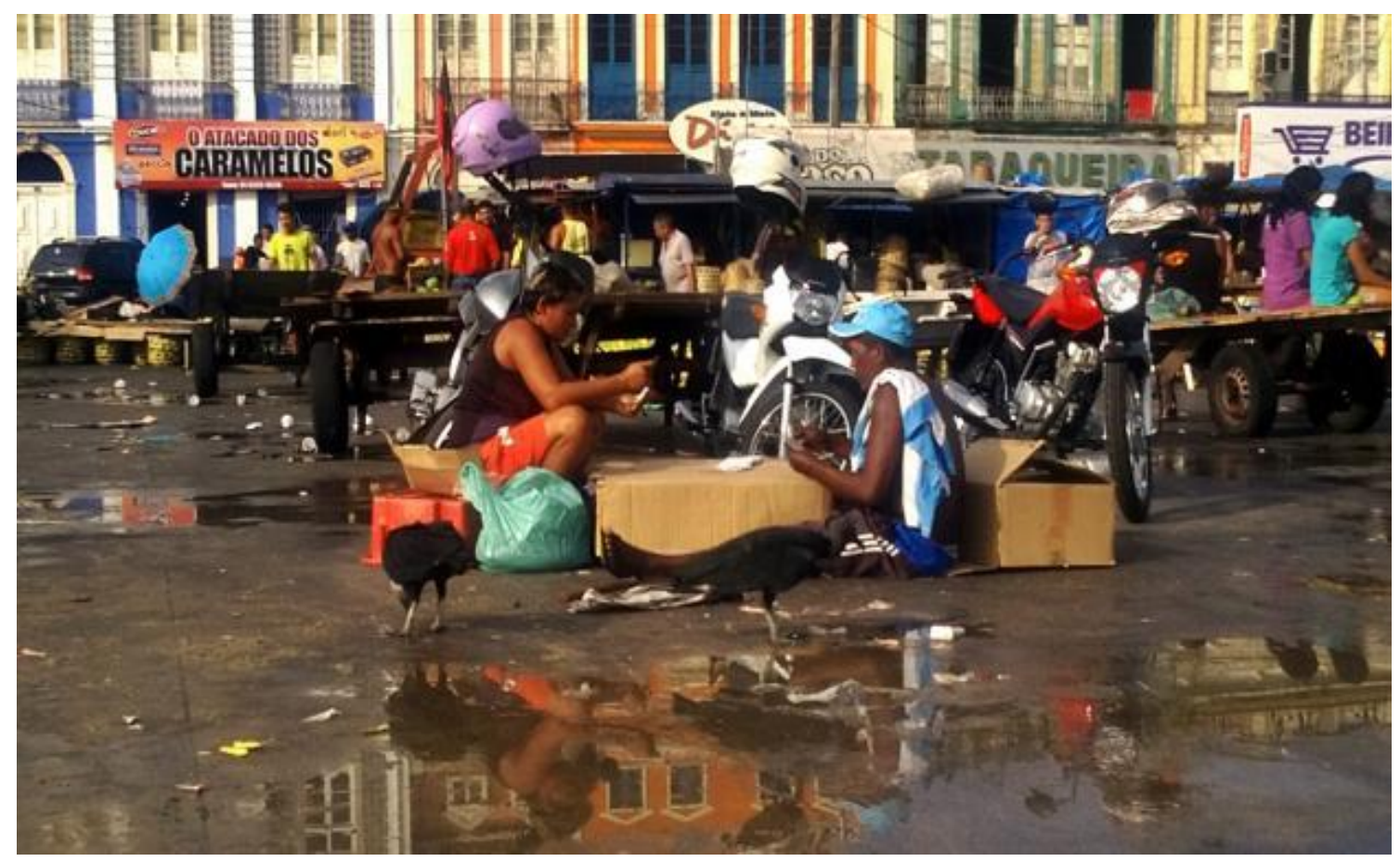

Finalmente, é preciso dizer que dos espaços de interação humanimal que a feira constitui emergem imagens de entrelaçamentos e de tensões entre cultura e natureza que duram no tempo e no espaço belenense, considerando-se os ritmos dos trabalhos e das sociabilidades humanos, da dispersão das aves e do fluxo das águas: elementos que a partir das suas interagências, contribuem para a configuração de paisagens coexistenciais interespecíficas na metrópole amazônica. Tais fenômenos, diante de suas complexidades, nos força a pensar sobre as maneiras pelas quais as relações com outras espécies moldam nossas próprias vidas desde que configuramos com elas o acontecer das paisagens ao longo do tempo, considerando as transformações e persistências de seus patrimônios bioculturais e sensíveis (Silveira, 2014) no mundo urbano de Belém.

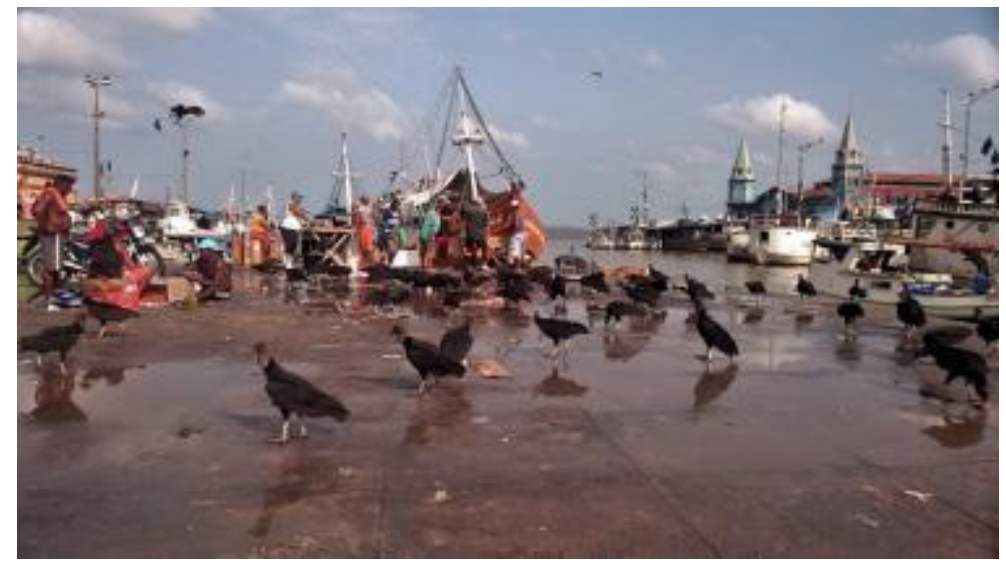




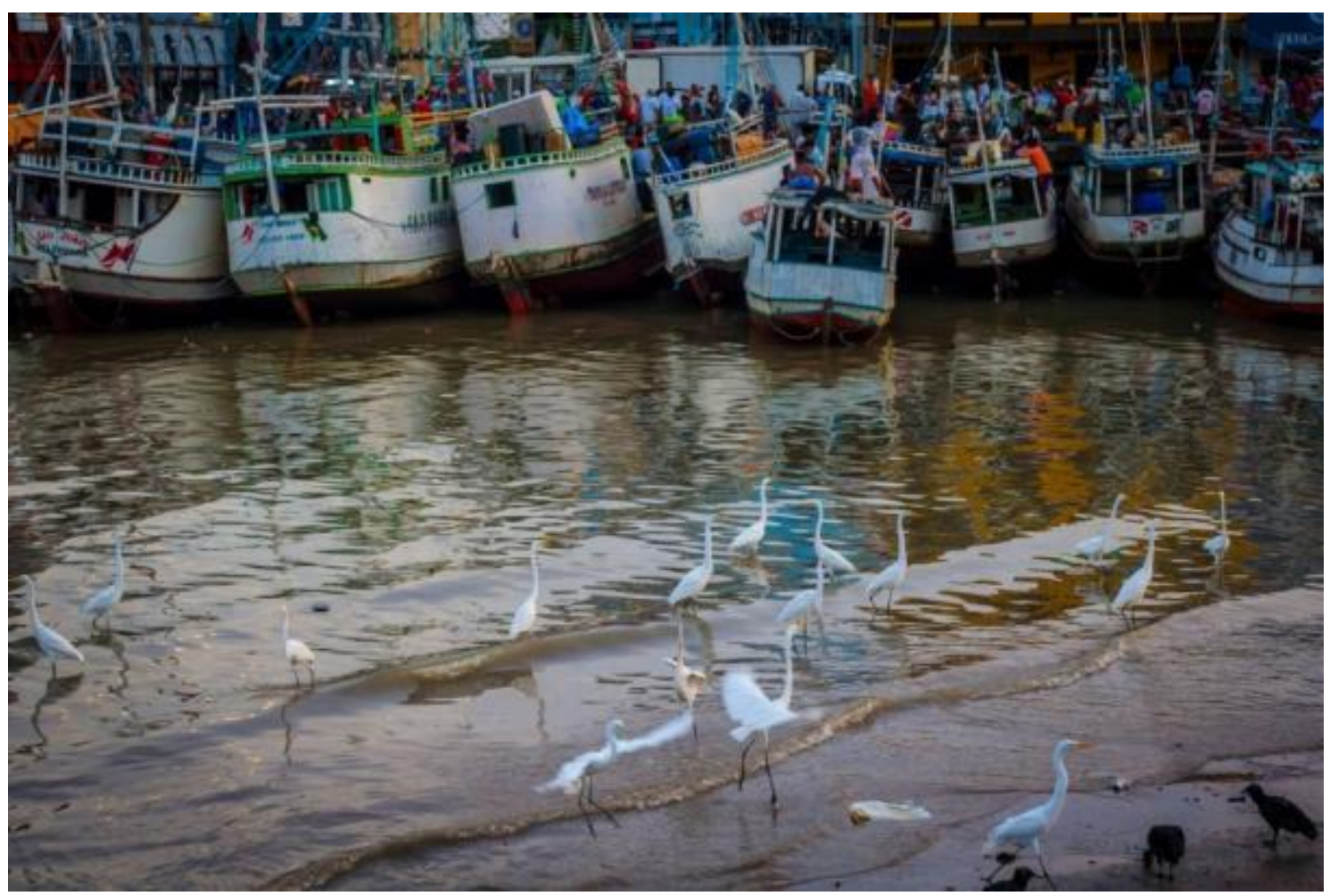

Fonte: Agenor Sarraf (Arquivo Pessoal).

\section{Referências}

CERTEAU, Michel de. A Invenção do Cotidiano. Artes de fazer. V. I. Rio de Janeiro: Vozes, 1994.

DAOU, Ana M. L. Natureza e civilização: os painéis decorativos do Salão Nobre do Teatro Amazonas. História, Ciências, Saúde-Manguinhos, V. 14, p. 51-71, 2007.

DOUGLAS, Mary. Pureza e Perigo. São Paulo: Perspectiva, 1976.

DURAND, Gilbert. As Estruturas Antropológicas do Imaginário. Lisboa: Presença, 1989.

HARAWAY, Donna. Manifeste des espèces de compagnie. Chiens, humains e tautrespartenaires. Paris: Éditions de l'éclat, 2010.

INGOLD, Tim. Being alive: essays on movement, knowledge and description. Londres: Routledge, 2011.

LEITAO, W. M.. Ver-o-Peso: estudos antropológicos no mercado de Belém V. 1. Belém: NAEA, 2010.

- Ver-o-Peso: estudos antropológicos no mercado de Belém, V. 2. Belém: Pakatatu, 2016.

LIMA, M. D. de. Ver-o-Peso, patrimônios(s) e práticas sociais. Uma abordagem etnográfica da feira mais famosa de Belém do Pará. Dissertação de Mestrado, PPGCS/UFPA, 2008.

MILLER, Daniel. Trecos, troços e coisas. Estudos antropológicos sobre a cultura material. Rio de Janeiro: Zahar, 2013.

ROCHA, Ana L. C. da; ECKERT, Cornelia. O tempo e a cidade. Porto Alegre: UFRGS, 2005. 
Etnografia da duração: antropologia das memórias coletivas em coleções etnográficas. Porto Alegre: Marcavisual. 2013.

SANSOT, Pierre. Variations paysagères. Paris: Klincksieck, 1983.

. Pour une esthétique des paysages ordinaires. Ethnologie Française,

CNRS/Réunion des Musées nationaux. 3(19): 239-243, 1989.

SILVEIRA, Flávio L. A. da. Paisagens do Bosque Rodrigues Alves, Belém (PA): considerações sobre a conservação do patrimônio urbano no contexto amazônico. Antíteses, 4(7): 230-257, 2014.

- As dinâmicas das paisagens de Belém (PA): memórias, ruínas e imaginários no mundo urbano. In: ANDRADE, Rubens (Org.). Amazônias, cidades e jardins: anatomia urbana e identidades paisagísticas. Rio de Janeiro: Paisagens Híbridas/Escola de Belas Artes: UFRJ, p. 75-121, 2016.

SILVEIRA, Flávio L. A. da.; SILVA, Matheus H. P. da.; MERCÊS, Raphael S. das. Voando baixo sobre humanos: garças e urubus na Pedra do Peixe, no Ver-o-Peso (PA). Revista Latinoamericana de Estudios Críticos Animales. V. 3, N. 2, p. 299-319, 2016.

TOCANTINS, Leandro. Santa Maria de Belém do Grão-Pará: instantes e evocações da cidade. Belo Horizonte: Itatiaia, 1987 [1963].

TUAN, Yi-Fu. Espaço \& Lugar. A Perspectiva da Experiência. São Paulo: DIFEL, 1983.

URRY, John. The Tourist Gaze and the "Environment". Theory, Culture \& Society, London, Newbury Park, New Delhi: Sage, V. 9, p. 1-26, 1992.

VELHO, Gilberto. Projeto e Metamorfose. Antropologia das Sociedades Complexas. Rio de Janeiro: Jorge Zahar Ed., 1994.

\section{Sites consultados:}

http://www.donaonete.com.br/

http://oswaldogoeldi.org.br/

http://www.catalogodasartes.com.br/Lista_Obras_Biografia_Artista.asp?idArtista=167

http://www.ufpa.br/cma/imagenscma.html

http://bernareale.com/home.html

http://g1.globo.com/pa/para/noticia/cartao-postal-de-belem-mercado-do-ver-o-peso-

inspira-fotografos.ghtml

Recebido em: 13/10/2017.

Aprovado em: 12/12/2017. 